\title{
Europe as ideological resource: the case of the Rassemblement National
}

\author{
Marta Lorimer
}

Accepted Manuscript.

The Version of Record of this manuscript has been published and is available in Journal of

European Public Policy 27 April 2020

http://www.tandfonline.com/doi/full/10.1080/13501763.2020.1754885

Abstract: Ever since they first entered the European Parliament in 1979, the EU has proven to be a strong legitimizing tool for far right parties, providing them with funding, visibility and a higher degree of credibility and respectability. While recent literature has explored some of these dynamics, the role of the far right's ideological positioning on Europe as a source of public legitimacy has been neglected. This paper argues that as a relatively new and contentious political issue, Europe can function as a powerful ideological resource for far right parties by allowing them to convey a more acceptable political message. This argument is illustrated through a case study of two key aspects of the Rassemblement National's ideological approach to the European Union: the party's claim to be pro-European but anti-EU and its opposition to EU integration on grounds of sovereignty.

Keywords: European Union, Far Right, Ideology, Legitimacy, Rassemblement National 
The construction of legitimacy has been a crux for far right parties ${ }^{i}$. Widely defined as radical, extreme, racist, xenophobic, and anti-Semitic, they have struggled to establish themselves as legitimate actors whose 'access to, and exercise of, power is rightful' (Beetham 2012: 120). In spite of their electoral successes, their fitness to rule has been frequently questioned in virtue of their dubious commitment to the existing (democratic) order or because of their xenophobic political programmes. In several countries, other political parties have refused to create alliances with them, putting in place a 'cordon sanitarie' to keep them out of power (Downs 2012: 35-38; for exceptions, see Albertazzi and McDonnell 2016, Fallend 2012, Zaslove 2012). Especially in their early years, their successes provoked strong negative reactions, as was the case in Austria after the Freedom Party first entered into a coalition government, or in France when Jean-Marie Le Pen made it to the run-off in the 2002 presidential election. Such reactions, while no longer as strong, still remain present when far right parties achieve positive results (suffice it to think of definitions of the 2014 EU Parliament elections as an 'earthquake').

To counteract such narratives, far right parties have sought to project an image of themselves as legitimate political actors. Some have famously rejected the label of extreme right, claiming to be at best 'extremists of common sense' (Salvini 2019). Others, such as the Rassemblement National, have undergone reviews of their language and practices in attempts to appear more moderate (Shields 2013, Stockemer and Barisone 2016). Their quest for legitimacy has had some success. Whereas the average vote for far right parties in Western Europe was $1.1 \%$ in the 1980 s, it reached $7.5 \%$ in the EU-28 in the 2010s (Mudde 2019: 19). Far right parties have joined in coalition governments in countries such as Italy and Austria and acted as parliamentary support to the centre-right in Denmark and the Netherlands among others (Akkerman and de Lange 2012, de Lange 2012). Furthermore, their positions have become more accepted and have even been incorporated in the platforms of mainstream parties seeking to win back voters from the far right (Gruber and Bale 2014, Herman and Muldoon 2019, Pytlas and Kossack 2015). 
The European Union (EU) has been one of their unwitting supporters in this process of legitimation. Electorally, the proportional system of representation employed in EU elections along with their 'second-order' nature (Reif and Schmitt 1980) made it easier for far right parties to gain representation (Hainsworth 2008: 83). This has also come with a gain in resources which could be used to consolidate their results and improve their standing in domestic elections (Reungoat 2014: 133-136, Schulte-Cloos 2018). Far from being mere passive beneficiaries of the process of European integration, far right parties have also sought to take advantage of the opportunities offered by it, for example by employing alliances in the European Parliament to enhance legitimacy at home (Startin 2010: 439, McDonnell and Werner 2019). Paradoxically, while far right parties have staunchly opposed the EU, and opposition to European integration is frequently painted as a marker of marginalisation for political parties (Ivaldi 2018: 286, Taggart 1998, Vasilopoulou 2018a), the EU has also been the provider of symbolic and material resources that have helped them become established actors (Fieschi 2000: 521).

Research so far has focused on how the far right's behaviour has provided them with resources for legitimation, however, less attention has been paid to considering whether their views on the European Union may have served similar purposes (for a partial exception, see Startin 2018). In other words, if one accepts that the EU has provided far right parties with a number of practical and symbolic resources that have enhanced their legitimacy, how did their positions on Europe contribute to this legitimation?

In this paper I argue that Europe can function as a powerful ideological resource for far right parties by allowing them to convey a more acceptable political message. This contention is grounded in the understanding that as a relatively new and contentious political issue to which there is no clear 'ideological' answer (Gaffney 1996: 19), Europe leaves parties leeway to determine their positions and present them in a more acceptable fashion. This argument is illustrated through a case study of key aspects of the Rassemblement National's (RN) ideological approach to the EU. The RN's 
historical influence on other far right parties (Rydgren 2007, Van Hauwaert 2014), its growing focus on issues of European integration (Vasilopoulou 2018b) and its marked concern with making an appropriate use of language (Camus 2015: 108-110) make it a compelling example for the article's core argument. Drawing on an in-depth interpretive analysis of party documents produced between 1978 and 2018, the article shows how two of the party's claims helped it address key criticisms moved against it: first, its assertion to be European and defend Europe from the EU; second, its appropriation of positively valued concepts such as sovereignty, autonomy and self-rule to oppose the EU. These claims, it is argued, helped the party present its best face to the world and construct a more legitimate image for itself.

The paper's contribution is two-fold. First, in line with the special issue's interest in studying the ideological dimension of European integration, it shows how Europe may function as an ideological resource available to parties looking for legitimation. Second, it offers an alternative view of the implications of far right parties adopting Eurosceptic positions. Instead of viewing them as markers of marginalisation, it suggests that opposition to the EU, if well packaged, may serve to legitimize far right actors.

At a time where far right parties have become a regular presence in the political make up of most European countries and even governmental forces in some of them, it is important to reflect on the causes of their success. Focusing on how the EU may have helped them achieve public legitimacy, this paper contributes to a wider debate on how they went from illegitimate fringe to legitimate contender for public office.

\section{Europe as an ideological resource}

Far right parties, the opening section has noted, often struggle to establish themselves as legitimate actors. Their inexperience with government is used as an argument to suggest that they lack the competencies to become credible political actors (for an example of this argument, see Ebner 2019). 
The nature of their beliefs, on the other hand, raises questions about whether if entrusted with power, they would uphold core values such as equality, solidarity, and non-discrimination. Being deemed unfit to govern, they are frequently presented as insufficiently 'coalitionable' and where possible, kept out of power.

Faced with such issues, there are two options available to far right parties in quest for legitimation. A first option available is to stick to their guns and hope that society adjusts to their presence. Such a process of 'normalisation' might be helped by social changes and by the actions of other actors such as mainstream parties. There is some evidence to suggest that this is what has been happening in recent years: while far right parties have maintained a consistent policy profile, other parties appear to be shifting to the right (Wagner and Meyer 2016). Given mainstream parties' tendency to co-opt elements of the far right agenda and mainstream their ideas (Herman and Muldoon 2019: 3-7, Mondon 2014), the strategy sounds reasonably sound and might eventually pay off. However, it takes time and rests on the hope that others will collaborate. In the meanwhile, parties may also wish to do something to facilitate the normalisation process.

The second option available to far right actors is to alter elements of their behaviour and beliefs to fit in with what is considered as legitimate in a given society. They might behave in such a way that suggests respect for existing institutions, or work within the boundaries of legality. Changes in behaviour, however, require being given the opportunity to exercise power, raising a chicken and egg issue: the far right's limited legitimacy keeps it out of power, but they need that power to construct credibility. ${ }^{\text {ii }}$

As an alternative, parties can seek to alter their message and tweak their ideology as to project a more acceptable image, as Marine Le Pen did with her previously cited process of dédiabolisation. This tweaking may take different forms: it may be of a rhetorical nature and build on less inflammatory language and the eschewal of certain topics; or, it may be of a substantive nature and entail the abandonment of controversial policy commitments and ideas. This appears as a promising avenue 
because it is less resource intensive, reasonably visible for voters and does not require one to already have power but merely to be competing for it.

Ideological change, however, can entail different costs. If the party is understood as a 'community of principle' (White and Ypi 2016: 14), changing these ideas creates a problem of internal credibility. Activists and voters may view the party as as betraying its long-standing commitments. This poses a conundrum for the party: on one hand, it needs to maintain its core of supporters and hence, demonstrate an attachment to the ideological commitments that keep them together. On the other hand, however, if it is to reach power and enact its programme, it needs to appeal to a larger constituency. In short, it needs to find a way to 'serve two masters' (Katz 2014). In this case, how can the party signal continuity with past principle but also get more people on board?

Europe offers an answer to this dilemma. As literature on Europeanization has stressed, Europe opens up a series of opportunities for political actors and offers them a number of strategic and ideological resources that they may 'use' to advance their agendas (Woll and Jacquot 2010). This is particularly helpful in the context of ideological change because it allows the parties to expand and alter their ideology at a relatively low cost and in a potentially positive fashion, thus balancing the imperatives of internal consistency and external validation.

First, the relatively new character and (until recently) low salience of the European issue means that parties are not wed to pre-existing commitments and hence have some leeway in terms of the position they adopt ${ }^{\text {iii }}$. While positions will usually be informed by existing beliefs (Hooghe et al. 2002, Szczerbiak and Taggart 2008: 13-14) and might need to be presented as consistent with the parties' other commitments, it also leaves more space for interpretation. In this process, the nature of European integration as an issue that has no clear ideological answer (Gaffney 1996: 16, Flood 2002: 7-11) also provides parties with additional space to select their positions. Because it sits uncomfortably on the Left/Right divide (Hooghe et al. 2002, Pirro and Taggart 2018) and can be interpreted in different ways depending on which aspect of the EU one is looking at (Szczerbiak and 
Taggart 2008: 238), the EU issue leaves parties enough space to frame it in a manner that is convenient for them. Thus, talking about the EU gives them an opportunity to introduce a new topic and a new approach in their ideological positioning, all the while entailing relatively low costs in terms of ideological consistency.

Second, far right parties can benefit from the political divisiveness of European integration. European integration, in fact, has divided political parties and electorates alike (suffice it to think the close results of referendums on European integration in the 1990s and 2000s). Opposition to the EU is also a common feature in countries across the European Union, making it a relatively uncontroversial position to hold (Eurobarometer 2019). This makes European integration a topic on which disagreement is acceptable and where it may be easier to build a legitimate image, as opposed to, an issue such as migration which will always leave parties open to criticism on grounds of extremism (see also Startin 2018: 76).

Europe may, in this sense, be conceived of as an ideological resource which allows far right parties to reorient their ideology in a more acceptable fashion and speak both to their traditional electorate and attract new supporters. ${ }^{\text {iv }}$ Its newness ensures that they can adapt their positions without appearing to give up on existing ideological commitments, thus preventing them from losing support from their own voters. Conversely, its divisiveness helps their position appear as more normal and potentially appealing to a larger constituency.

The remainder of this paper provides an empirical illustration of this argument by showing how key aspects of the RN's positioning on Europe allowed it to address criticisms moved against its ideology. Given the RN's central place in the far right party family, its historical influence on other members of the far right (Rydgren 2007, Van Hawwaert 2014) and its growing focus on issues of European integration (Vasilopoulou 2018b) it was considered to be a particularly relevant case to study. In addition, because the $\mathrm{RN}$ is a party that has placed an important weight on using acceptable language in the political battle (Camus 2015: 108-110), and whose members have acknowledged that the EU 
helped it construct legitimacy (Reungoat 2014: 130,134), it is the most likely to have deliberately taken advantage of Europe as an ideological resource. Drawing on an in-depth interpretive analysis based on close textual reading of 65 documents (complete list in online appendix) including manifestoes, opinion articles, interviews, and speeches ${ }^{v}$ produced between the party's 1978 attempt to participate in European elections and its latest presidential campaign in 2017, and dealing either specifically, or in some depth, with European issues, the following sections consider two sets of positions developed by the RN: its claim to be pro-European but anti-EU, and its appropriation of positively valued concepts such as sovereignty, autonomy and self-rule to oppose the EU. These arguments, frequently present in the entire corpus, are here illustrated by referring to a small number of quotes which summarise most clearly the discourses brought forward by the party.

\section{Pro-European, anti-EU: Rejecting accusations of closed nationalism by claiming a European}

\section{identity}

Legitimacy has been an issue for far right parties because they have been viewed as pushing forward unacceptable ideas concerning, for example, the relationship with minorities and the functioning of the institutions of liberal democracy. The reason for the former is frequently ascribed to their 'closed' exclusionary nationalism or nativist ideology which views Others as inherently dangerous and in need to be kept at bay (Minkenberg 2000: 180, Mudde 2007: 19). In diverse societies, this is viewed as particularly critical because it hinders the integration of new citizens, but also poses problems in terms of broader commitments to values such as equality and the protection of human rights. Less prominently, there is also a concern that this kind of closed nationalism could lead to aggressive foreign policies and destabilisation. At the heart of this concern is the view of far right parties as some $21^{\text {st }}$ century reincarnation of the interwar fascists movements responsible for World War Two (a concern which is open to debate: for opposing positions see Copsey 2018, Mammone 2009: 177, 
Taguieff 2014) . While far right parties in Europe in general and the RN in particular have not been too keen to start wars with other countries, this worry still lingers on.

The integration of Europe in the RN's ideology has given the party ammunition to reject such claims by providing it with an opportunity to claim 'Europeanness' against the EU (see also Glencross 2019, Brown 2019). Within a context in which advocating for a closed and exclusionary nation accompanied by the proposition of highly restrictive policy measures is frowned upon, this attachment to Europe may contribute to projecting an image of 'openness', clearing a path to acceptability through (moderate) transnationalism.

At the heart of the RN's claim of Europeanness is the party's recognition of a European civilization, distinct from others and bearer of a proud heritage. The features of this civilization are already discussed in Jean-Marie Le Pen's programmatic book 'Les français d'abord', in which he defines Europe as
A historic, geographic, cultural, economic and social ensemble. It is an entity destined for action. Europe is currently divided [...] but it guards the possibilities for rebirth, should she rediscover a spiritual, intellectual and political unity and all that has been its spirit: that is, a will to act for civilisation, to refuse to be submerged and vanquished. (Le Pen 1984: 154)

Europeans, in a similar fashion, are defined as those who 'Defied the universe, attempted to conquer it, and brought modern economic and technologic progress to the world [...] Europeans must be proud of themselves and of their contribution to the world' (Le Pen 1985: 189-190). Beyond recognising this 'European civilisation', early RN documents also stress the party's belonging to this civilization (e.g. Le Pen 1984: 164), flanking its national identity with a European one.

From the middle of the 1980s, following the Single European Act, the RN started pitting this European civilization against the EU, and increasingly presented itself as the defender of the former against the latter. This division between Europe and the EU (a distinction popular on the far right, but 
not exclusive to it: e.g., Vlaams Belang 2014, Freiheitliche Partei Österreichs 2011, but also Johnson 2016) emerged as a result of the intellectual influence of the Nouvelle Droite and the Club de l'Horloge (Zúquete 2018: 229ff, Bar-On 2008), and is particularly evident in the following passage from a 1991 party guide, where it is noted that

The debate on Europe is completely distorted, because there are in fact two radically different conceptions of Europe.

One is founded on the idea that the world is destined to homogenise and unite, and that Europe in this perspective is nothing but a stage. [...]

The other is founded on the idea that European nations are menaced in their survival and they have to unite to preserve their identity and retrieve their power. $[\ldots]$

The first conception is that of a cosmopolitan or globalist Europe, the second is that of a Europe understood as a community of civilisation.

The first one destroys the nations, the second one ensures their survival. The first one is an accelerator of decline, the second an instrument of renaissance. The first is the conception of the Brussels technocrats and of establishment politicians, the second is our conception. (Front National ${ }^{\mathrm{vi}}$ 1991: 115)

Further reinforced by the Maastricht Treaty, this distinction between 'Europe' and 'the EU' recurs in party documents throughout the nineties and noughties, and in spite of the 2011 leadership change in the RN, survives in the party to this day. The RN's 2009 European election programme, for example, stressed that they were not 'against Europe' but 'resolutely against the fraud that consists [...] to build a super state [...] without even building a truly European ensemble but a euro-globalist space' (FN 2009). As recently as 2017 , Marine Le Pen claimed that 'even though we are resolutely opposed to the European Union, we are resolutely European, I'd go as far as saying that it is because we are European that we are opposed to the European Union' (Le Pen 2017b; see also Le Pen 2019). 
Pronounced shortly after the presidential debacle of 2017, when many accused Le Pen of holding extreme views of Europe as she campaigned to leave the euro, this passage may be seen both as a direct response to such critiques of extremism, but also, as a traditional party discourse stressing continuity with the party's past.

Claiming to be 'European' helps the RN dispel some doubts concerning the nature of its beliefs because it presents it as more 'open' than commonly thought. The appeal to a shared European heritage can put to rest concerns about its likelihood of starting a new European conflict because it suggests that if in power, it would be unlikely to attack its good neighbours. More importantly, it also counters the view that its nationalism is limited to the national space because appealing to a 'European' identity suggests an affiliation that goes beyond the nation state. In this sense, Le Pen's claim to be 'resolutely European' or the RN's idea of defending a true vision of Europe moderates the party's image because it creates an alternative definition of the party in which exclusion is underplayed and a certain measure of openness is stressed.

Stressing openness does not entail that all boundaries disappear, but rather, that they are moved to a different level. Mirroring the fact that Europeanism lends itself to the defence of identity projects of various types, including nationalist ones (Delanty 1995: 130-131, Gosewinkel 2018), the RN's appeal to Europe still keeps a strict boundary between 'Us' and 'Them' alive. While this border is brought to a higher level, it remains present, ensuring that the party remains internally credible with those who support because of its 'closed' nationalism. In this sense, it may be thought of as a form of 'constructive ambiguity' which while altering and nuancing the core message of the party in an acceptable way for outsiders, also maintains a level of continuity that helps preserve internal credibility. Thus, by adding an element of transnationalism to their ideology, the RN can appear as more 'open' to other peoples and cultures, albeit (and importantly) within clear boundaries. 


\section{Normalisation through appropriation: reclaiming sovereignty, autonomy, and independence}

\section{from the $E U$}

If far right parties have suffered from a legitimacy deficit, it is not only because of the content of their ideology, but also because of the way in which it has been presented as a set of beliefs borne out of crisis and falling outside the scope of 'normal politics'. This assumption has been defined by Mudde (2010) as the 'normal pathology' hypothesis, which posits that far right parties hold values that are alien to Western democracies. The assumption made is that far right parties are fundamentally different compared to other parties, which could make them appear as illegitimate or holding unacceptable positions because they are not aligned with the values of their own societies.

Against this backdrop, the inclusion of European issues in the RN's ideology has given the party an opportunity to refocus it on issues of sovereignty, autonomy and independence and present itself as respectful of key aspects of the national polity. Countering the narrative of the far right as an 'extreme' actor living on the edge of society, it helped the RN fashion itself as the defender of values and ideas commonly considered as unquestionably good. Importantly, their critique of the EU on these grounds carries the 'ring of truth' because it targets aspects of the construction which are considered as problematic even by mainstream actors.

Early RN documents made virtually no mention of the issue of national sovereignty in a European context. In the context of the Cold War, what did come up was a discussion of the need for Europe to be autonomous, powerful and independent ('imperial', in Le Pen's 1989 expression; see also Mégret 1989). The ratification of the Maastricht treaty brought sovereignty front and centre in the RN's understanding of Europe. Transforming the EU from an economic project to an unmistakably political union, Maastricht opened the space for a critique of European integration based on appealing to a nation's ability to make its own choices.

Starting from the early 1990s, one of the central lines of criticism adopted by the RN against the EU is that the EU diminishes a nation's power to make its own laws by shifting the centres of decision- 
making away from it and empowering obscure 'unelected technocrats.' In a 2007 speech, for example, Jean-Marie Le Pen argued that decision-making power had 'quit the Elysée and Matignon to install itself in the European quarter of Brussels', while a 1999 article in the party magazine Français d'abord accused the EU of pushing for the ultimate demise of national democracy, with popular sovereignty being replaced by 'expert' decision making (FN 1999). The party's 2004 EU election manifesto offers a helpful summary of the accusations the RN moved against the EU throughout the years when it claims that

A nation's sovereignty is its ability to take decisions freely and for itself. It refers then to the notions of independence and exercise of political power by a legitimate government.

The entire history of the European construction consists of depriving States of their sovereignty. Firstly, because Europe has seen its areas of intervention becoming larger, to the point that today they cover the whole of the economic, social, and political spheres. Then, because the organization and functioning of the European institutions, as well as their decision-making, tend more and more to lead the notion of Nation-State itself to disappear and to entrust power to technocrats in Brussels. (Front National 2004)

What is notable about this passage is that in constructing a critique of the EU, the RN redeploys a number of concepts ('sovereignty', 'self-rule', 'independence', 'legitimate government') which are consistent with the party's nationalist ideological core (e.g., Davies 1999), but which would also be normally considered as essential within a modern democratic state. Marine Le Pen adopted a similar approach in the first point her 2017 programme when she claimed the need to 'Retrieve our liberty and the control of our destiny by returning its sovereignty to the French people' and reform the EU to reach 'a European project respectful of the independence of France, of national sovereignties and of the interests of the peoples' (Le Pen 2017a). As with the 2004 programme, she appropriated these 
central and broadly accepted notions of 'liberty', 'independence' and 'interest of the people' to oppose the EU, all the while maintaining an ideologically consistent message.

What is important about this choice of words is that it helps normalise the $\mathrm{RN}$ by allowing it to present itself as broadly aligned with important values in the national polity. When the party appeals to a concept such as sovereignty, for example, it is appealing to a concept that while remaining contested in several empirical and theoretical terms (Bellamy and Castiglione 1997), remains a central concept in constitutional law and discourse, and is thus heavily embedded as a core part of politics (Troper 2012: 351). Within the French context specifically, the relevance of the principle of sovereignty, as well as its nature as an attribute of the Nation and not merely of the State, can be inferred by its presence in the opening sections of the Constitution, with the French Constitution proclaiming an attachment to the principle of 'national sovereignty' in the preamble and dedicating its second constitutional article to it.

Appropriating widely shared values of the state system in the context of opposition to the EU helps the RN present itself as more aligned with what is considered 'moral and proper' and hence, legitimate. While remaining consistent with its existing beliefs, it allows it to claim that it is committed to certain elements of politics that are not exceptional, but rather, shared across the party spectrum. Thus, like its attachment to Europe, it maintains continuity with the past for existing supporters, but also presents a more acceptable face to outsiders. Additionally, even if their positions could still be perceived as radical, they will no longer appear as outside the realm of normal politics, but rather, as radical expressions of it.

The fact that the RN's positions may be able to resonate with such foundational narratives should also not come as a surprise but should rather be seen as the result of the persistence of elements of nationalism in contemporary polities. In fact, while nationalism is often given a bad name, leading some far right politicians to reject the label 'nationalist' in favour of the more positive sounding 'patriot' (Lorimer 2019), it is also deeply embedded in European societies, particularly though its 
relationship with the nation-state as a space built on and consolidated by nationalism. In day-to-day life, nationalism is at the heart of many societies in both 'banal' and 'everyday' forms (Billig 1995, Skey and Antonsich 2017) and many of the assumptions of how the nation state works are derived from the nationalist premises injected at the time of foundation and reproduced in laws, understandings, and daily practices. In this sense, the RN may benefit from this 'constant reproduction of a sense of national belonging' (Calhoun 2017: 20-21) because it makes its message sound coherent with the underpinnings of society.

The party's ability to appropriate widely shared values is not limited to its positions on Europe but may be viewed as an expression of their role as 'pathological normalcies' which are unexceptional from an attitudinal or an ideological point of view (Mudde 2010). However, what they say about sovereignty with respect to the EU might be particularly helpful to the construction of legitimacy because the way in which the EU is commonly seen as affecting these concepts might give it the 'ring of truth.' The EU, in fact, unlike 'regular' international organisations, challenges these key assumptions of politics both through its institutional structures and through the way it functions. By creating a 'pan-European' assembly, it reviews the nation as the natural space of politics. In its executive politics, binding legislation and the need to balance the interests of all member states challenge ideas of national self-rule because laws are not made exclusively by the nationals and are unlikely to ever correspond to the 'ideal' of any individual state (e.g. Scharpf 2006). In legal terms, the principles of direct effect and the supremacy of EU law indicate that in certain areas, the nation is unable to rule itself as it would conflict with EU law (Alter 2003). These issues are not raised exclusively by parties such as the $\mathrm{RN}$, but form part of a broader set of critical approaches to the status of democracy and sovereignty in the EU. Debates on the EU's 'democratic deficit' and its complex relationship with popular sovereignty (Brack et al. 2019, Follesdal and Hix 2006, Mair 2013), and more recently, critical assessments of the EU's actions in times of crisis (Fromage and van den Brink 2018, White 2019) are features of academic and political analyses of the EU beyond the far right. Within the French context, they also chime with strong levels of party-based and popular 
Euroscepticism (e.g., Eurobarometer 2019, Goodliffe 2015). Criticism of the EU on these grounds, then, might be particularly strong because it suggests that the $\mathrm{RN}$ is not only holding positions that are acceptable, but also saying things that sound credible and consistent with the analyses of other actors around them.

\section{Conclusion}

This article started with the observation that while far right parties have been among the staunchest opponents of the European project, the EU has provided them with a number of resources to enhance their legitimacy. Focusing specifically on how the inclusion of Europe in their ideology may have served similar purposes, the article argued that Europe has been an ideological resource allowing far right parties to convey a more acceptable political message. This argument was illustrated through a case study of the RN's approach to the EU ehich focused on its claims to be 'pro-European but antiEU' and its appropriation of positively valued concepts such as sovereignty, autonomy and self-rule to criticise the EU. In doing so, it has contributed to existing literature on political ideologies and the European Union by showing how Europe can function as an ideological resource. Contributing to recent literature on the role of Euroscepticism in the rise of the far right (Pirro and Taggart 2018), it also suggests that far right Euroscepticism, when correctly phrased, can actually help the parties establish themselves as legitimate political actors rather than entrench their position of opponents to the system.

A note of caution is needed here: while Europe may help the parties, it is unlikely to legitimize them by itself. First, their positions on Europe may still raise some doubts. For example, the claim to be 'European' does not manage to dispel the doubt that the RN may think of 'Europe' as a racial construct. While this may be framed in terms of cultural affinity and 'civilisationism' (Brubaker 2017), it does not fully dissipate doubts about how that cultural affinity is operationalised in practice. Second, legitimization will in any case require some buy-in and support from other actors. What 
Europe allows the parties to do is present their best face, but whether others believe them is beyond their control. This can help explain why in spite of strong continuities in the discourses of Jean-Marie Le Pen's Front National and Marine Le Pen's RN observed in this paper (but also by others, e.g. Alduy and Wahnich 2015), the latter has been significantly more successful than the former. Marine Le Pen has not changed the party's message significantly; rather, she has been acting in a radically different political environment where Europe has become more salient and others have helped her message resonate.

In addition to requiring some caution, it is also important to point towards some of the limitations of this study. Most obviously, the fact that the paper has focused more on individuating mechanisms in a single case study than on testing them means that it leaves questions about generalizability and effectiveness unanswered. In other words, while it has suggested that Europe may function as an ideological resource, it has not attempted to study whether this was indeed the case across countries and whether it was effective. Future confirmatory research may wish to explore this question with reference not only to the RN, but also, to far right parties more broadly. There are some good reasons to expect other similar parties to adopt similar positions on Europe: as was mentioned earlier, the claim to be 'European' but 'anti-EU' is not an exclusive feature of the RN but is present in other parties as well. In a similar vein, other parties in the family appeal to concepts such as liberty, democracy, autonomy, sovereignty and self-rule (suffice it to think, for example, of the presence of these terms in the names of parties such as the Party for Freedom and Forum for Democracy in the Netherlands, or the Party for Freedom and Direct Democracy in the Czech Republic). This final note should also serve as a reminder of the nature of these concepts as essentially contested (Gallie 1955): while many actors may appeal to them, how they interpret them will differ across lines and across time. It may be worth spending more time understanding how these parties specifically understand such concepts, in which ways they significantly differ from other groups' usages, and indeed, if the uses they adopt are compatible with those of others. 
${ }^{\mathrm{i}}$ The term far right is used as an umbrella term to encompass parties of the extreme and radical right (see also Vasilopoulou 2018a: 6, Halikiopoulou and Vlandas 2019).

${ }^{i i}$ Empirically, it is also unclear that such changes in behaviour are what far right parties go for when in power (e.g., Akkerman et al. 2016, Albertazzi and Mueller 2013), or that there is an appetite amongst their supporters for such moderation (Heinisch 2003: 101-102).

${ }^{\text {iii }}$ While the process itself is not new, its politicisation is a relatively new matter which started mainly from the late 1980 s and early 1990s (Hooghe and Marks 2009).

iv This may be done deliberately by the parties, for example as part of a strategic choice to alter their language, but may also be the unintended consequence of processes of ideological adjustment engendered by the introduction of a new issue. ${ }^{v}$ The use of a variety of sources was meant to limit the extent to which one was capturing purely externally directed material (see Mudde 2000 for a more extensive discussion of this) and/or exclusively electoral statements.

vi The Front National changed name to Rassemblement National in 2018. Documents produced by the party before 2018 are cited following the original nomenclature. 


\section{References}

Akkerman, T. and de Lange, S.L. (2012) 'Radical Right Parties in Office' Government and Opposition 47: 574-596.

Akkerman, T., de Lange, S. L., \& Rooduijn, M. (2016) Radical right-wing populist parties in Western Europe: into the mainstream? London: Routledge.

Albertazzi, D., \& Mueller, S. (2013) 'Populism and Liberal Democracy: Populists in Government in Austria, Italy, Poland and Switzerland' Government and Opposition 48.3: 343-371.

Albertazzi, D., \& McDonnell, D. (2016) Populists in power, London: Routledge.

Alduy, C., \& Wahnich, S. (2015) Marine Le Pen Prise Aux Mots: Decryptage du nouveau discours frontiste, Paris: Seuil.

Alter, K. J. (2003) Establishing the supremacy of European law the making of an international rule of law in Europe, Oxford: Oxford University Press.

Bar-On, T. (2008) 'Fascism to the Nouvelle Droite: The Dream of Pan-European Empire' Journal of Contemporary European Studies 16: 327-345.

Beetham, D. (2012) 'Political Legitimacy', in E. Amenta, N. Kate, \& A. Scott. (Eds.), The WileyBlackwell Companion to Political Sociology. Chichester: John Wiley \& Sons, 120-129.

Bellamy, R., \& Castiglione, D. (1997) 'Building the Union: The Nature of Sovereignty in the Political Architecture of Europe' Law and Philosophy 16.4: 421-445.

Billig, M. (1995) Banal nationalism, London: Sage.

Brack, N., Coman , R. \& Crespy, A. (2019) 'Unpacking old and new conflicts of sovereignty in the European polity' Journal of European Integration 41.7: 817-832. 
Brown, K. (2019) 'When Eurosceptics become Europhiles: far-right opposition to Turkish involvement in the European Union' Identities, 1-22.

Brubaker, R. (2017) 'Between nationalism and civilizationism: the European populist moment in comparative perspective’ Ethnic and Racial Studies 40.8: 1191-1226.

Calhoun, C. J. (2017) 'The Rhetoric of Nationalism, in M. Skey \& M. Antonsich (Eds.), Everyday nationhood: theorising culture, identity and belonging after Banal nationalism, London: Palgrave Macmillan, 17-30.

Camus, J.-Y. (2015) 'Le Front National et la Nouvelle Droite', in S. Crépon, A. Dézé, \& N. Mayer (Eds.), Les faux-semblants du Front National, Paris: Presses de Sciences Po, 97-120.

Copsey, N. (2018) 'The Radical Right and Fascism', in J. Rydgren (Ed.), The Oxford handbook of the radical right, New York: Oxford University Press, 105-121.

Davies, P. (1999) The National Front and France: ideology, discourse, and power, London: Routledge.

de Lange, S. L. (2012) 'New Alliances: Why Mainstream Parties Govern with Radical Right-Wing Populist Parties' Political Studies 60.4: 899-918.

Delanty, G. (1995) Inventing Europe: idea, identity, reality, London: Macmillan.

Downs, W. M. (2012) Political extremism in democracies combating intolerance, New York: Palgrave Macmillan.

Ebner, J. (2019) 'Austria's crisis is a lesson for Europe: far-right parties are unfit to govern', The $\begin{array}{llll}\text { Guardian, } & 19 & \text { May. } & \text { Retrieved }\end{array}$ https://www.theguardian.com/commentisfree/2019/may/23/austria-crisis-europe-far-rightfreedom-ibiza-scandal 
Eurobarometer (2019) 'Public Opinion in the European Union' Standard Eurobarometer 92 Autumn 2019, Brussels: European Commission. Retrieved from https://ec.europa.eu/commfrontoffice/publicopinion/index.cfm/General/index

Fallend, F. (2012) 'Populism in government', in C. Mudde \& C. Rovira Kaltwasser (Eds.), Populism in Europe and the Americas: Threat or Corrective for Democracy? Cambridge: Cambridge University Press, 113-135

Fieschi, C. (2000) 'European institutions: the far-right and illiberal politics in a liberal context' Parliamentary Affairs, 53.3: 517-531.

Flood, C. (2002) Euroscepticism: A problematic concept (illustrated with particular reference to France ) Paper presented at the UACES 32nd Annual Conference, Belfast.

Follesdal, A., \& Hix, S. (2006) Why There is a Democratic Deficit in the EU: A Response to Majone and Moravcsik. Journal of Common Market Studies, 44(3), 533-562.

Freiheitliche Partei Österreichs. (2011) Party Programme of the Freedom Party of Austria. Retrieved from https://www.fpoe.at/themen/parteiprogramm/parteiprogramm-englisch/

Fromage, D. \& van den Brink, T. (2018) 'Democratic legitimation of EU economic governance: challenges and opportunities for European Legislatures' Journal of European Integration 40.3: 235-248.

Front National (1991) Militer Au Front, Paris: Editions Nationales.

Front National (1999) 'Le Front National pour restaurer notre identité nationale face à l'Europe fédérale' Français d'Abord, November (first half): 10-13, 28-29.

Front National (2004) Programme pour les elections europeennes de 2004.

Front National (2009) Programme 'Europe' du Front National: leur Europe n'est pas la notre! Voilà l'Europe que nous voulons. 
Gaffney, J. (1996) Political parties and the European union, London: Routledge.

Gallie, W. B. (1955) 'Essentially Contested Concepts' Proceedings of the Aristotelian Society 56: 167-198.

Glencross, A. (2019) “'Love Europe, hate the EU”: A genealogical inquiry into populists' spatiocultural critique of the European Union and its consequences' European Journal of International Relations.

Goodliffe, G. (2015) 'Europe's salience and 'owning' Euroscepticism: Explaining the Front National's victory in the 2014 European elections in France' French Politics, 13(4), 324-345.

Gosewinkel, D. (2018) 'Europe antilibérale ou Anti-Europe? Les conceptions européennes de l'extrême droite française entre 1940 et 1990' Politique européenne 62.4 152-179.

Gruber, O., \& Bale, T. (2014) 'And it's good night Vienna. How (not) to deal with the populist radical right: The conservatives, UKIP and some lessons from the heartland' British Politics 9.3: 237254.

Hainsworth, P. (2008) The extreme right in Western Europe. New York: Routledge.

Halikiopoulou, D., \& Vlandas, T. (2019) 'What is new and what is nationalist about Europe's new nationalism? Explaining the rise of the far right in Europe' Nations and Nationalism 25.2: 409-434.

Heinisch, R. (2003) 'Success in opposition - failure in government: explaining the performance of right-wing populist parties in public office' West European Politics 26.3: 91-130.

Herman, L. E., \& Muldoon, J. B. (2019) Trumping the mainstream: the conquest of mainstream democratic politics by the populist radical right, London: Routledge.

Hooghe, L., \& Marks, G. (2009) 'A Postfunctionalist Theory of European Integration: From Permissive Consensus to Constraining Dissensus’ British Journal of Political Science 39.1: 123. 
Hooghe, L., Marks, G., \& Wilson, C. J. (2002) 'Does Left/Right Structure Party Positions on European Integration?' Comparative Political Studies 35: 965-989.

Ivaldi, G. (2018) 'Contesting the EU in times of crisis: The Front National and politics of Euroscepticism in France' Politics: 38.3: 278-294.

Johnson, B. (2016) 'Boris Johnson: "We are leaving the EU, not Europe"” BBC News, 13 October. Retrieved from https://www.bbc.co.uk/news/av/uk-politics-37641405/boris-johnson-we-areleaving-the-eu-not-europe

Katz, R. S. (2014) 'No man can serve two masters: Party politicians, party members, citizens and principal-agent models of democracy' Party Politics 20.2: 183-193.

Le Pen, J.-M. (1984) Les Français d'abord, Paris: Carrère Michel Lafon.

Le Pen, J.-M. (1985) Pour la France: programme du Front National, Paris: Albatros.

Le Pen, J.-M. (1989) Europe: discours et interventions, 1984-1989, Paris : Groupe des Droites européennes.

Le Pen, M. (2017a) 144 engagements présidentiels. Retrieved from https://rassemblementnational.fr/le-projet-de-marine-le-pen/

Le Pen, M. (2017b) Discours de Marine Le Pen à la journée des élus FN au Futuroscope de Poitiers. Retrieved from https://www.youtube.com/watch?v=fyty5HSaAx0.

Le Pen, M. (2019) Discours de Marine Le Pen à la Mutualité pour les Européennes. Retrieved from https://www.bfmtv.com/mediaplayer/video/l-integralite-du-discours-de-lancement-decampagne-de-marine-le-pen-pour-les-europeennes-1131658.html.

Lorimer, M. (2019) '’Ni droite, ni gauche, francais!" Far right populism and the future of Left/Right politics', in L. E. Herman \& J. B. Muldoon (Eds.), Trumping the mainstream: the conquest of mainstream democratic politics by the populist radical right, London: Routledge, 145-162 
Mair, P. (2013) Ruling the void: the hollowing of Western democracy, London: Verso.

Mammone, A. (2009) 'The Eternal Return? Faux Populism and Contemporarization of Neo-Fascism across Britain, France and Italy' Journal of Contemporary European Studies 17: 171-192.

McDonnell, D., \& Werner, A. (2019) International populism: The radical right in the European Parliament, London: Hurst.

Mégret, B. (1989) 'Les principes fondateurs de notre Europe’ La Lettre de Jean-Marie Le Pen, May (second half): 3 .

Minkenberg, M. (2000) 'The Renewal of the Radical Right: Between Modernity and Anti-modernity' Government and Opposition 35.2: 170-188.

Mondon, A. (2014) 'The Front National in the Twenty-First Century: From Pariah to Republican Democratic Contender?' Modern \& Contemporary France 22: 301-320.

Mudde, C. (2000) The ideology of the extreme right, New York: Manchester University Press.

Mudde, C. (2007) Populist radical right parties in Europe, Cambridge: Cambridge University Press.

Mudde, C. (2010) 'The Populist Radical Right: A Pathological Normalcy' West European Politics, 33.6: $1167-1186$.

Mudde, C. (2019) The Far Right Today, Cambridge: Polity.

Pirro, A. L. P., \& Taggart, P. A. (2018) 'The populist politics of Euroscepticism in times of crisis: A framework for analysis' Politics 38.3: 253-262.

Pytlas, B, \& Kossack, O. (2015) 'Lighting the fuse: the impact of radical right parties on party competition in Central and Eastern Europe', in M. Minkenberg (ed), Transforming the Transformation? The East European Radical Right in the Political Process, London: Routledge, 105-136. 
Reif, K., \& Schmitt, H. (1980) 'Nine second-order national elections - A conceptual framework for the analysis of European election results' European Journal of Political Research, 8.1: 3-44.

Reungoat, E. (2014) 'Mobiliser l'Europe dans la compétition nationale. La fabrique de l'européanisation du Front national' Politique européenne 43.1: 120-162.

Rydgren, J. (2007) 'The Sociology of the Radical Right' Annual Review of Sociology 33: 241-262.

Salvini, M. (2019) “"Per Di Maio è piazza degli ultrà? Siamo estremisti del buonsenso”'. Retrieved from https://video.corriere.it/salvini-per-maio-piazza-ultra-siamo-estremistibuonsenso/2a392f88-79a8-11e9-84cc-19261c23ea92?refresh_ce-cp

Scharpf, F. W. (2006) 'The Joint-Decision Trap Revisited' Journal of Common Market Studies, 44.4: 845-864.

Schulte-Cloos, J. (2018) 'Do European Parliament elections foster challenger parties' success on the national level?' European Union Politics 19.3: 408-426.

Shields, J. (2013) 'Marine Le Pen and the 'New' FN: A Change of Style or of Substance?' Parliamentary Affairs 66.1: 179-196.

Skey, M., \& Antonsich, M. (2017) Everyday nationhood: theorising culture, identity and belonging after Banal nationalism, London: Palgrave Macmillan.

Startin, N. (2010) 'Where to for the Radical Right in the European Parliament? The Rise and Fall of Transnational Political Cooperation' Perspectives on European Politics and Society 11.4: 429449.

Startin, N. (2018) '"Euromondialisme" and the growth of the radical right', in B. Leruth, N. Startin, \& S. M. Usherwood (Eds.), Routledge handbook of Euroscepticism, London : Routledge

Stockemer, D., \& Barisione, M. (2016) 'The “new” discourse of the Front National under Marine Le Pen: A slight change with a big impact' European Journal of Communication 32.2: 100-115. 
Szczerbiak, A., \& Taggart, P. A. (2008) Opposing Europe? the comparative party politics of Euroscepticism, Oxford: Oxford University Press.

Taggart,P. (1998) 'A touchstone of dissent: Euroscepticism in contemporary Western European party systems’ European Journal of Political Research 33.3: 363-388.

Taguieff, P.-A. (2014) Du Diable En Politique: Réflexions sur l'antilepénisme ordinaire, Paris: CNRS Éditions.

Troper, M. (2012) 'Sovereignty’, in M. Rosenfeld \& A. s. Sajó (Eds.), The Oxford Handbook of Comparative Constitutional Law. Oxford: Oxford University Press.

Van Hauwaert, S. M. (2014) 'Trans-national diffusion patterns and the future of far right party research: Independence vs. interdependence' European Journal of Futures Research 2.1: 54.

Vasilopoulou, S. (2018a) Far right parties and Euroscepticism: patterns of opposition. London: Rowman \& Littlefield International.

Vasilopoulou, S. (2018b) ‘The Radical Right and Euroskepticism', in J. Rydgren (Ed.), The Oxford Handbook of the Radical Right, Oxford: Oxford University Press, 122-141

Vlaams Belang. (2014) Uw Stock Achter de Deur, Verkiezingsprogramma. Retrieved from https://www.vlaamsbelang.org/wpcontent/uploads/2016/08/20140318ProgrammaVerkiezingen2014.pdf

Wagner, M., \& Meyer, T. M. (2017) ‘The Radical Right as Niche Parties? The Ideological Landscape of Party Systems in Western Europe, 1980-2014' Political Studies 65.1_suppl: 84-107.

White, J. (2019) Politics of Last Resort: Governing by Emergency in the European Union, Oxford: Oxford University Press.

White, J., \& Ypi, L. (2016) The meaning of partisanship, Oxford: Oxford University Press. 
Woll, C., \& Jacquot, S. (2010) 'Using Europe: Strategic action in multi-level politics’ Comparative European Politics 8: 110-126.

Zaslove, A. (2012) 'The populist radical right in government: The structure and agency of success and failure' Comparative European Politics 10.4: 421-448.

Zúquete, J. P. (2018) The identitarians: the movement against globalism and Islam in Europe, Notre Dame: University of Notre Dame Press. 